\title{
The Impact of Efficiency on Bank Spreads in Commercial Banks in Kenya
}

\author{
Jane Isiaho $^{1^{*}} \quad$ Prof. Lucky Yona ${ }^{2}$ \\ 1.PHD student, Swiss School of Management \\ 2.Eastern and Southern African Institute of Management
}

\begin{abstract}
This study analysed the impact of efficiency on bank spread. Secondary data was collected from the audited financial statements of thirteen commercial banks in Kenya selected through purposive sampling on the basis of data availability for all variables covering the period 2009 to 2018. The data was arranged in panel form and analysed using correlation and regression statistics with the help of SPSS and STATA softwares. Kenya's banking sector is largely inefficient and this has the highest influence on interest rate spread. Much as policy and regulation has done so much to influence the macro-environment by way of reducing information asymmetry and introducing sufficient competition in the sector. There remain internal inefficiencies that drive costs in the banks which in turn are covered for by increasing interest rate spreads. Proper credit screening methodologies and sufficient deployment of properly skilled employees to ensure effective relationship management for loan appraisal and administration is required. Stable operating systems and timely customer issue resolution will also go a long way in curbing losses. This study has contributed to the existing academic and professional knowledge on the subject by providing empirical evidence of the nature of relationship between efficiency and bank spread in Kenya's commercial banks.
\end{abstract}

Keywords: Efficiency, Bank spread

DOI: $10.7176 / \mathrm{JESD} / 12-12-10$

Publication date:June $30^{\text {th }} 2021$

\section{Introduction}

Efficiency may be defined as the ability to accomplish a task at minimum possible cost. The study of bank efficiency in Malaysia by Kamarudin et al defines bank efficiency as a concept that comprises cost, revenue as well as profitability (Kamarudin et al., 2019). When costs are minimized and revenues maximized then the resulting effect is higher profitability. According to Bader et al. (2008), the results of efficiency in the banking industry is increased intermediation, better prices for the customer and better profitability for the intermediary. A good number of studies have identified bank efficiency as a determinant of interest rate spread using such variable indicators like cost to income ratio, return on assets and staff costs (Gesang Raharjo et al., 2014; Ghasemi \& Rostami, 2015; Rebei, 2014).

The last 10 years have seen tremendous innovation in banking services to embrace the use of technology, mobile phone banking and third party bank agents to increase access to customers. Kenya's banking sector has seen a number of wide branch networked banks adopt technology that has enabled one branch banking so that customers can access services from any branch at no additional cost. Internet based banking solutions have also come in to enable customers transact and perform multiple payment transactions like salary processing and supplier payments from the comfort of their offices. This has greatly reduced the cost of transacting as customers no longer need to write cheques and visit one bank after another to deposit whenever they are paying suppliers or employees. Since these transactions are now prepared and sent to the clearing house by the customers themselves, this has also saved banks a lot of man hours and the staff cost thereof. The integration of mobile telephone networks to banking systems has taken this access to even higher levels as now access to bank transactions away from the branch is possible not only to corporates but even individuals with small transactional accounts. Agency Banking is a model that enables ordinary business people to be licensed as agents of the bank to receive and pay cash, and open accounts on behalf of the bank. This again has been made possible by technological innovation and further eases access to banking even where there is no branch network.

Mobile money services have greatly increased access to financial services that has seen loan accounts increase from one million to 3 million between 2007 and 2013 and deposit accounts up from 2 million to 18 million over the same period. As at 2015, the number of customer accounts had grown to 35.1 million, a growth largely credited to the use of the mobile phone to open and operate bank accounts by 3 major banks. This revolution is expected to solve the problem of access to financial services and its relative costs (Mwega, 2014). These tremendous innovations notwithstanding, the perception that spread is high in Kenya has persisted culminating in the passage of the law capping interest rates in 2016. This study will attempt to shade light to this by examining the effect of efficiency on bank spread. 


\section{Research problem}

The Ho and Saunders' dealership model, deemed to be the foundational model for the determination of bank interest margins views the bank as a dealer in the loans and deposits market (Ho \& Saunders , 1981). The bank, in its dealership is faced with a funding or re-investment risk arising from the non-contemporaneous arrival times of loans and deposits. To secure a positive return therefore, the bank needs to make loans at a rate higher than the money market rates to cover for the refinance and credit risks. At the same time it needs to accept deposits at a rate lower than the money market rates to cover for the re-investment risk (Maudos \& Fernández De Guevara, 2004). The optimum mark-up set on the loans and deposit interest will depend on four factors namely: average size of transactions realized by the bank, interest rate volatility, the degree of risk aversion by bank managers and the structure of the market (Männasoo, 2012). The main criticism of the Ho and Sounders' dealership model is that it does not take into account the cost structure of the bank. According to Maudos and Guevara (2004), banks incur costs in the process of mobilizing deposits and making loans. To maximize the shareholders' wealth, banks must provide for these costs when arriving at the mark ups set for loans and deposits interest rates. Even in the absence of market power and any form of risk, margins must always be positive in order to cater for the costs of the intermediary.

Bank executives, according to the agency theory, tend to be driven by selfish motives to set high salaries and other emoluments that are usually in conflict with the organization's goal of shareholder- value maximization. Shareholders on the other hand will incur additional costs in a bid to ensure the actions of managers are directed towards maximization of value and returns to the shareholder. When these costs are passed on to the customer by way of higher lending or lower deposit rates or both, the result is wider interest rate spread. Mensah and Abor (2012) carried out a study to examine the impact of agency conflict on interest rate spread in Ghana and found that managers set wider spreads if they believed they were able to extract higher emoluments for themselves by so doing hence confirming the influence of agency conflict on interest rate spread (Mensah \& Abor, 2012).

With a less developed financial system, banks remain the main source of finance for economic development. (Koffie et al, 2014). Financial reforms and liberalization are expected to narrow interest rate spreads by increasing efficiency and competitiveness in the banking industry. To achieve this, Kenya has been on a series of sustained financial liberalization and reforms since the early 1990s. This notwithstanding, interest rate spread in Kenya has remained high at $9.21 \%$ (CBK Statistical Bulletin, 2015b) in 2015 as compared to the world's average of 5.3\% (Appendix table A 1). Kenya has put in place so many interventions to try and address this wide spread since the interest rate liberalization in 1991 but the spread has not been contained at acceptable levels. Interest rate spreads still remain high and prohibitive of access to credit in Kenya. With costs taking up 70\% of the sector's total incomes as at 2018, (CBK, 2018) Kenya's banking sector remains cost inefficient and it is important to examine how this impacts on bank spreads.

\section{Literature review}

\subsection{Bank efficiency}

Bank efficiency refers to a bank's ability to use of resources to generate revenue. A bank is considered efficient when it is able to generate maximum revenue at minimum cost given the resources it has. Efficiency is demonstrated in two ways: by how well a bank is able to control its costs and by how it is able to invest in assets that generate maximum revenue. Cost to income ratio, staff costs ratio and return on assets ratio have often been used in research to proxy for bank efficiency.

Banks incur costs in mobilizing deposits, evaluating and giving loans as well as monitoring recovery of the same. Such costs include: administrative costs, staff costs, interest expense, provisions for bad debts and other operating expenses. Higher operating costs result in higher marginal costs which banks tend to cover by adjusting lending rates upwards resulting to wide interest rate spread. Operating costs are therefore expected to be positively associated to interest rate spread (Rusuhuzwa \& Karangwa, Mathias; Nyalihama, 2016). High operating costs are also likely to include costs resulting from the inefficiency of bank operations which is usually associated with wider spreads. Operational inefficiency leads to higher costs of intermediation resulting in higher bank spreads as banks increase their lending rates and/or lower their deposit rates to cover for the inefficiencies. A number of empirical studies measure this variable as the ratio of operating costs to total assets (Kiptui, 2014 and Koffie et al., 2014). Ahokpossi (2013) uses overheads to average assets as a proxy for operational inefficiency. Banks need wide spreads to cover for higher overhead costs (Rebei, 2014). According to his study, a 1\% fall in salaries and wages is associated with a $0.5 \%$ to $0.7 \%$ drop in interest rate spread (Rebei, 2014). According to the Agency Theory, managers allocate themselves high emoluments and cover for the cost by passing it on to customers by way of increased interest spread. On average, staff costs make up 49.7\% (appendix table A 2) of total operating costs in Kenya's banking sector and this has remained largely the same despite the great strides the sector has made in technological innovation.

Operational inefficiency leads to higher costs of intermediation resulting in higher bank spreads. Ahokpossi (2013) uses overheads to total assets as a proxy for operational inefficiency. Inefficient banks are associated with 
higher margins irrespective of bank size. This is seen in that when market share is interacted with inefficiency the result is insignificant. Inefficient banks will tend to raise lending rates and lower deposit rates to cover their high costs. Operating costs have a positive relationship to net interest margins (Maudos \& Fernández De Guevara, 2004; Khediri \& Ben-Khedhiri, 2011; Ugur \& Erkus, 2010; Gounder \& Sharma, 2012). Chortareas et al. (2012) studied the role of competition and efficiency in the determination of interest rate margins in Latin America against the back drop of extensive financial reforms which appeared to have done little to lower interest margins. According to economic theory, efficient banks are in a position to reduce their costs and allocate more market share to themselves. This theory also argues that a competitive environment is able to create a more efficient and focused banking system. The theory therefore concludes that high spreads are an indication of low efficiency and noncompetitive market conditions. Chortareas, Georgios E.; Garza-Garcia, Jesus G.and Girardone ( 2009) studied interest rate spread determinants in the Mexican banking sector basing their investigation on the Market Power theories (SCP and RMP) and the Efficient Structure(ES) hypothesis. The research was based on the 20 largest banks in Mexico over the period 1996-2003. The researchers formulated a regression model on the basis of the theories above and carried out analysis using Random Effects Panel data estimation. The investigation did not support the SCP hypothesis as there was no evidence of a relationship between concentration and market share with interest rate spread. The research however confirmed the Efficient Structure hypothesis as it found a significant negative relationship between operational efficiency and interest rate spread.

In Peshev's (2015) study based on Bulgaria, administrative inefficiency is positive depicting the fact that inefficiency in banks is compensated for through wider interest rate spreads. Rusuhuzwa, Karangwa and Nyalihama (2016) carried out an empirical examination of interest rate determinants in the Rwandan market using the Generalized Moments Method (GMM) and found operating costs; credit risk and inflation have a positive effect on interest rate spread. There is therefore need to consolidate to allow economies of scale in a bid to cut costs and improve loan screening and administration to mitigate credit risk.

Return on assets (ROA), measures the bank's ability to generate revenue from assets owned. It is an indication of management's efficiency and ability. In the study conducted by Ghasemi and Rostami (2015), return on assets is both a measure of profitability as it represents the profit per unit of assets and an efficiency measure as it shows the banks' ability to manage use of capital and financial resources efficiently. Sometimes high interest margins are not an indicator of inefficiency but rather a targeted long run interest margin that ensures a certain desired rate of return by shareholders given their capital investment in an environment of high information asymmetry and credit risk. In the Study on the determinants of interest rate spread in Pakistan, Afzal and Mirza (2012) also used return on assets as a measure of operational efficiency. Raharjo et al. (2014) found Return on assets to be the most positively related to net margins than all the other variables they studied, suggesting that banks in Indonesia raise their net incomes by increasing interest margins to cover increased operating costs.

Commercial banks need to be profitable in order to sustain their intermediation activities (Dhal \& Ansari, 2013). Profits contribute to the bank's ability to remain in business in two ways. First is that profits can be ploughed back into the bank's balance sheet as capital reserves. Secondly, good returns incentivize shareholders and attract more investors hence assuring the bank of continued stable capital. A stable financial system contributes significantly to sustainable economic growth. Additionally, where management is motivated by profit maximization, they may elect to achieve the same by increasing interest spread thus the positive relationship between interest margins and return on assets in this study. The study recommends attention to market concentration, market power and level of legal reserve requirements in order to address high spreads in Costa Rica (Romero \& Rodriguez, 2011).

According to Peshev's (2015) study of interest rate determinants in Bulgaria, low profitability prompts banks to increase their lending rates and reduce their deposit rates to secure better results in future. This increases interest rate spread. Higher return on equity and return on assets prompt banks to expand interest spread in order to get even better ratios in subsequent years more so in Bulgaria where interest income is the main contributor to bank profitability. Consistent with theory, Ghasemi and Rostami (2015) also found return on assets to be significant and positive. High return on assets is however not always achieved by increase in lending rates or reduction in deposit rates. On the contrary, high return on assets may be an indicator that a bank is able to use its assets more efficiently. Afzal and Mirza (2012), found a positive and significant relationship between interest rate spread and return on assets suggesting that banks that use their assets more efficiently are able to record higher spread resulting in higher profitability. Accordingly, banks with higher return on assets have the power to improve the efficiency of the financial system by reducing spread.

\subsection{Bank spread}

There are two common approaches to the calculation of interest rate spread in empirical studies. The first is termed as the ex-ante spread and is the difference between the actual lending rate and deposit rate as per contract with customers. These rates are in the public domain and easily observable in actual rates in the market. The second one is termed as ex-post spread and is the difference between the average realised interest income and average 
realised interest expense. The average interest income is calculated as total interest income received divided by the average stock of loans and advances while the average interest expense is arrived at by dividing the interest expense by the average stock of total deposits (Giordano \& Lopez, 2015).

Whereas the ex-ante spread is the most direct indicator of the actual difference between lending and deposit rates, it is not always easy to get bank level data on the same. Besides, banks charge different lending rates for different product categories and different lending durations. Customers and their businesses also carry different risk profiles and are likely to be charged interest in accordance to their respective risk classes. Deposits also attract different interest rates according to the term and the total relationship value of individual customers. For this reason, it is difficult to find a singular way of measuring the difference between lending and deposit rates (Gounder \& Sharma, 2012). As a result of this, scholars have come up with different ex-post indicators to measure interest rate spread. Our study will adopt two spread measures: interest rate spread which is a direct measure of spread and gross margin which captures the effect of non-traditional intermediation activities

\section{Conceptual framework}

Conceptual framework refers to the way ideas are organized in order to achieve the objective of the research. The main objective of this research is to examine the effect of efficiency on bank spread. This objective will be achieved through correlation and regression analysis of data drawn from thirteen banks in Kenya covering 2009 to 2018 . The independent variable to be studied is bank efficiency measured by cost to income ratio, staff costs ratio and return on assets against bank spread measured by interest rate spread and gross margin as the dependent variables. Figure 3.1 below graphically shows the operationalization of these research variables.

\section{Figure 1 Conceptual framework}

Independent Variables

\section{Dependent Variable}

\begin{tabular}{|l|}
\hline Efficiency \\
- \\
-
\end{tabular}

Bank spread

- Interest rate spread

- Gross margin

Source: Researcher, 2021

\subsection{Independent variables}

Bank efficiency refers to the delivery of services in a cost effective manner. Bank efficiency has been measured in different ways by different scholars. In some cases, efficiency has been measured by traditional financial ratios like return on assets, return on investment and cost-income ratios (Afzal \& Mirza, 2012). Chortareas et al. (2012), employed the use of technical and scale efficiency estimated through data envelopment analysis. Our study will adopt the following variable indicators for bank efficiency: cost to income ratio, staff costs and return on assets.

\section{Cost to income ratio}

The efficiency ratio calculated as operating costs divided by operating income measures the bank's ability to control is costs and thereby increase total bank income (Raharjo et al., 2014; Dumicic \& Ridzak, 2016). Our current study adopts the preceding calculation for this variable. Inefficient banks incur more costs to generate income. These costs are usually transferred to customers through increased interest on loans or reduced interest on deposits thereby increasing interest rate spread (Ahokpossi, 2013; Ghasemi \& Rostami, 2015; Raharjo, Hakim, Manurung, \& Maulana, 2014 Were \& Wambua, 2013). Ahokpossi (2013) uses overhead to average assets ratio as a proxy for efficiency and finds that inefficient banks pass their costs to consumers by way of higher interest margins irrespective of bank size. Efficiency, proxied by operating costs to operating income is found to have significant influence on interest rate spread in Indonesia (Gesang Raharjo et al., 2014). Costs are generally incurred in the process of mobilizing deposits, assessing customer risk profiles for lending and monitoring loan portfolio performance. Inefficiency in any part of this process increases the relevant cost hence this variable is an indicator of operational efficiency. Banks will increase their mark up on loans and reduce that on deposits to meet such costs hence widening the spread. The higher the ratio the higher the costs and therefore higher spread is expected. This ratio is therefore expected to have a positive association with bank spread.

\section{Staff costs ratio}

The influence of staff costs on interest rate spread is hinged upon the agency problem. According to the agency theory, manager's allocate themselves super normal benefits if they have the opportunity to do so and sometimes to the detriment of shareholder value creation (Mensah \& Abor, 2012). In an environment where such benefits are pegged on financial deliverables as is often the case in the banking industry, managers will be motivated to exceed on their financial growth targets by sometimes taking on excess risks. Such risks are then mitigated through higher loan interest rates or lower deposit rates thereby creating wide interest rate spread. In the study exploring the relationship between agency conflict and interest rate spread based on banks in Ghana, Mensah and Abor (2012) 
found executive compensation to be associated with high interest rate margins. Rebei (2014) found a positive association between interest spread and staff costs in his study of interest spread determinants in the Solomon Islands. This study will adopt the measure of staff costs to total assets ratio for this variable (Mensah \& Abor, 2012; Rebei, 2014). A positive relationship for staff costs ratio and bank spread is hypothesized.

\section{Return on assets}

Return on assets is the percentage of profits a firm earns from the deployment of its total resources. The more efficient a firm is in its deployment of resources, the better their return on assets. Afzal and Mirza (2012) associated the positive relationship between return on assets and interest rate margin to the more efficient deployment of assets by the banks that recorded higher return on assets. Of course the common perception especially by proponents of interest rate controls is that banks impose wide spreads primarily to drive higher profits as measured by return on assets among other indicators. It is calculated as a ratio of net income to total assets (Peshev, 2015; Ghasemi \& Rostami, 2015; Afzal \& Mirza, 2012). In this study, we adopt the calculation used by Georgievska et al., (2011) and Bonga, (2016) which uses average total assets to control for within year changes. A positive relationship with bank spread is expected.

The following summary of hypothesis is formulated to examine the relationship between efficiency and bank spread:

H1: There is a positive relationship between inefficiency and bank spread of commercial banks in Kenya.

This will be tested alongside the following minor hypotheses:

H1a: Cost to income ratio has a positive influence over bank spread.

H1b: There is a positive relationship between staff cost ratio and bank spread

H1c: Return on assets has a positive relationship with bank spread.

\subsection{Dependent variable}

Bank spread is defined generally as the difference between bank's lending rate and deposits rate. To cover for the costs of mobilizing deposits and providing and administering loans, intermediaries add a premium to the lending interest rates over and above the cost of funds and set the deposit rate at a margin below the cost of funds rate. The result is that there will always be a difference between the lending and deposit rates known as the interest spread. Interest spread is an indicator of the cost and efficiency of financial intermediation and an understanding of the factors that influence it is crucial for regulators, policy makers and the individual banks, all of who are interested in a more efficient cost effective banking sector. Interest rate spread, proxied by two measures as indicated below is the dependent variable of our study.

(i). Interest rate spread calculated as the difference between average realised interest income and average realised interest expense. Average realised interest income is derived as the ratio of interest income to average loans and advances whereas the average interest expense is the ratio of interest expense to average deposits (Giordano \& Lopez, 2015).

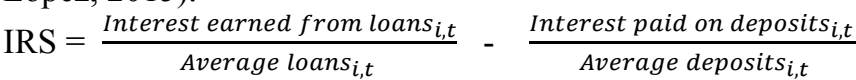

(ii). Gross margin to include the effect of non-traditional bank activities (Valverde \& Fernandez, 2007).

GRNIM $=\frac{\text { Total }_{\text {income }}, t}{\text { Total }_{\text {assets }}, t, t}$

Where $i$ is the individual bank and $t$ the respective year.

\section{Methodology}

The study employed descriptive statistics by use of mean scores and standard deviations of the variables to study the trends and variations between banks according to size and ownership type. Regression and correlation analyses were employed to evaluate the magnitude and direction of the relationships between the dependent variable and the independent variables using SPSS and STATA statistical softwares. These relationships were then used to draw conclusions with respect to the stated hypotheses.

\subsection{Data reliability and validity}

Validity in research refers to the extent to which a concept is accurately measured. It is the degree to which the instrument used measures what it is designed to measure. On the other hand, Reliability is the extent to which results are consistent and replicable (Heale \& Twycross, 2015; Mohajan, 2017).

For the multiple regression equation to yield reliable results, the following assumptions must be satisfied: The existence of a normal distribution and linear relationship, absence of multicollinearity, auto-correlation and heteroscedasticity. There was a linear relationship between the dependent and independent variables as seen in the P-P Plots and scatter diagram tests in appendix figure 1. The box-plots in appendix figure 1 also reveal that there were no outliers. Multicollinearity between the independent variables is addressed by removal of the cost income ratio from the correlation and regression analysis (Table 1 and 2). Heteroscedasticity and autocorrelation problems 
are resolved by the use of a robust regression analysis estimator. According to Moundigbaye et al. (2018), there are two estimation models that control for both heteroscedasticity and autocorrelation in regression analysis. The first one, the Feasible Generalized Least Squares (FGLS) is applicable where the time periods are equal or greater than the cross sections. The FGLS model controls for cross-section dependence by default. Panel Corrected Standard Errors (PCSE) estimator is used where this is not the case. Besides, PCSE produces more accurate standard error estimates without losing on efficiency. Unlike the FGLS estimator, PCSE controls for both cross section dependence and heteroscedasticity by default. The PCSE is therefore best for hypothesis testing. Owing to the presence of both autocorrelation and heteroscedasticity, this study will adopt the Panel Corrected Standard Error (PCSE) estimator to check for robustness of regression results and hypothesis testing. Similar studies done by Rebei (2014) and Koffie et al. (2014) have also employed the same estimation technique because of its ability to yield reliable results

Table 1: Validity tests

\begin{tabular}{|c|c|c|c|}
\hline \multicolumn{4}{|c|}{ Multicollinearity tests } \\
\hline & \multirow[t]{2}{*}{ VIF } & \multicolumn{2}{|c|}{ Pearson Correlation coefficients } \\
\hline & & IRS & GRNIM \\
\hline CIR & 4.598 & 0.023 & -0.098 \\
\hline SCR & 1.459 & $0.577 * *$ & $0.652 * *$ \\
\hline ROA & 3.750 & $0.267 * *$ & $0.412 * *$ \\
\hline \multicolumn{2}{|c|}{ Autocorrelation tests } & \multicolumn{2}{|c|}{ Normality tests } \\
\hline & Durbin Watson & Kolmog & Shapiro Wilk \\
\hline IRS & 0.563 & $0.200 *$ & 0.450 \\
\hline GRNIM & 0.921 & $0.200 *$ & 0.384 \\
\hline
\end{tabular}

Source: Researcher, 2021

Table 2. Multicollinearity tests without CIR

\begin{tabular}{lccc}
\hline \multicolumn{4}{c}{ Multicollinearity tests without CIR } \\
\hline & VIF & Pearson Correlation coefficients \\
SCR & & IRS & GRNIM \\
ROA & 1.084 & $0.577^{* *}$ & $0.652^{* *}$ \\
\hline
\end{tabular}

Source: Researcher, 2021

\section{Research findings}

\subsection{Descriptive statistics}

Two different measures were used to proxy spread as the dependent variable in this study namely: interest rate spread which captures the spread of traditional intermediation activities and gross margin that captures both traditional and non-traditional banking activities. On the overall the interest rate spread in Kenya's banking sector between 2009 and 2018 remained on a downward trend save for 2012 and 2016. To note is that the two years preceded the country's general elections and were a time of rising interest rates signalled by high Treasury bill rates of 12.76 in 2012 and 8.51\% in 2016 (appendix tables A 3). Both gross margin and interest rate spread flattened with the introduction of the law capping interest rates suggesting that interest income is still a significant contributor to bank revenues and therefore materially influences the gross margin (appendix table A 4).

Interest rate spread and gross margin overall mean scores are more or less the same (interest rate spread mean of $10.2 \%$ against gross margin of $10.3 \%$ ) suggesting that bank loans form a significant part of bank assets as well as sources of income. Although gross margins posted the lower maximum mean scores, they also recorded higher minimum mean scores in the overall. The medium banks recorded the lowest mean (SD) for both measures at $0.089(0.035)$ and $0.090(0.028)$ for interest rate spread and gross margin respectively. Unlike the large banks which by virtue of their size can exercise dominance in some markets, the medium banks have to contend with competition all the time. As such they must pay a premium to mobilize deposits in order to continue their lending activities. Notwithstanding the high cost of deposits, they must remain competitive with their lending rates in order to retain borrowing customers. Because of these two scenarios, their interest rate spread and gross margins are the lowest and at a single digit.

Bank efficiency as measured by cost to income ratio remained above the industry desired benchmark of below $50 \%$ for the whole period under review with an overall mean (SD) of 0.6616(0.23008). Though the lowest mean (SD) for cost income ratio was registered at 0.4086(0.07795), the standard deviations remained wide throughout the period and the maximum values high with the highest mean (SD) being 1.0439(0.19639). Small banks recorded the highest staff cost ratio at a mean (SD) of 0.0424(0.00843) while the medium sized banks recorded the lowest of $0.0237(0.01158)$ notwithstanding the fact that three out of the five banks sampled under this category reported losses in some of the years covered by the study. They however reported the highest cost to income ratio, an indication that more needs to be done to achieve operational efficiency among the medium sized banks. The four 
loss making banks reviewed are to be found in the medium and small categories hence the low return on asset ratios under these two tiers. On the overall, the return on assets for the sector is low at a mean (SD) of $0.0267(0.01871)$.

As shown in table 3 below, state-owned banks are more inefficient than privately-owned banks with a cost to income ratio mean $(\mathrm{SD})$ of $0.9381(0.21238)$ and $0.6113(0.19547)$ respectively. This situation may be attributed to rising operating costs and bad debts provisioning. The non performing debt position for government banks stood at $60 \%$ while that for private banks was $11.7 \%$ (appendix table A 3). The mean (SD) of 0.6113(0.19547) posted by the privately-owned banks which is the lowest comparatively, is still higher than the industry accepted cost to income ratio of $50 \%$ leading to the conclusion that Kenya's banking sector is inefficient in terms of the costs incurred to generate the current income levels. Further, the return on assets mean (SD) of 0.0036(0.01882) for government owned banks compared to $0.0309(0.01538)$ for privately owned banks points to the inefficient deployment of assets in the sector generally with government banks fairing worse off than their privately owned counterparts. The staff cost ratio mean for government owned banks of 0.0407 with a very small standard deviation of 0.00813 compared to the lower mean for privately owned banks at 0.0271 with a higher standard deviation of 0.010741 may be indicative of more competitive salary negotiating by employees of privately owned banks and the effect of performance based remuneration schemes.

Table 3 Mean (SD) by bank, ownership and size

\begin{tabular}{lccc}
\hline & CIR & SCR & ROA \\
\hline ALL BANKS & $0.662(0.230)$ & $0.029(0.011)$ & $0.027(0.019)$ \\
LARGE BANKS & $0.558(0.067)$ & $0.030(0.007)$ & $0.040(0.010)$ \\
MEDIUM BANKS & $0.675(0.247)$ & $0.024(0.011)$ & $0.022(0.015)$ \\
SMALL BANKS & $0.880(0.281)$ & $0.042(0.008)$ & $0.006(0.020)$ \\
GOVT BANKS & $0.938(0.212)$ & $0.041(0.008)$ & $0.004(0.019)$ \\
PRIVATE BANKS & $0.611(0.195)$ & $0.027(0.011)$ & $0.031(0.015)$ \\
\hline
\end{tabular}

Source: Researcher, 2021

\subsection{Comparative analysis by bank ownership and size}

Whereas Kenya's banking industry cannot be said to be efficient going by all the efficiency indicators selected in the study, private banks have fared better in all three. The cost to income ratio for government owned banks is significantly higher than that of their private counterparts at mean (SD) of 0.9381(.21238) against 0.6113(.19547) for private banks. This situation is mostly contributed to by the high incidence of bad debts leading to high provisions and depressed interest incomes in government banks. Government owned banks had a mean of $4 \%$ on staff costs with a minimum score of $2.8 \%$ higher than the mean of $2.7 \%$ for privately owned banks. On the return on assets indicator, the privately owned banks recorded a mean of 3\% despite some of the individual banks within the cluster reporting losses during the period. With a maximum mean of $6.6 \%$, it is evident that some banks within this category are doing very well in terms of return on assets. Small banks posted the highest mean (SD) of 0.9283(0.203) with the bank that recorded the highest mean coming from this category. Understandably, this category also posted the highest mean (SD) for staff costs and subsequently the least return on assets. As already pointed out earlier small banks reported losses during the period of economic turbulence amidst increased loan defaults and rising interest paid on deposits.

Table 4 Comparative analysis by bank ownership and size

\begin{tabular}{|l|l|l|l|l|l|l|l|l|l|}
\hline & \multicolumn{4}{|c|}{ CIR } & \multicolumn{3}{c|}{ SCR } & \multicolumn{3}{c|}{ ROA } \\
\cline { 2 - 11 } & Mean(SD) & Min. & Max & Mean(SD) & Min. & Max & Mean(SD) & Min. & Max \\
\hline Govt. & $0.938(0.212)$ & 0.62 & 1.34 & $0.041(0.008)$ & 0.028 & 0.057 & $0.004(0.019)$ & -0.04 & 0.04 \\
\hline Priv. & $0.611(0.195)$ & 0.27 & 1.33 & $0.027(0.011)$ & 0.008 & 0.060 & $0.031(0.015)$ & -0.01 & 0.07 \\
\hline Large & $0.558(0.067)$ & 0.43 & 0.68 & $0.030(0.007)$ & 0.02 & 0.05 & $0.040(0.010)$ & 0.02 & 0.06 \\
\hline Medium & $0.675(0.247)$ & 0.33 & 1.33 & $0.024(0.011)$ & 0.01 & 0.06 & $0.022(0.015)$ & -0.01 & 0.05 \\
\hline Small & $0.928(0.203)$ & 0.65 & 1.34 & $0.042(0.008)$ & 0.03 & 0.06 & $0.006(0.020)$ & -0.04 & 0.03 \\
\hline & $0.662(0.230)$ & 0.27 & 1.34 & $0.029(0.011)$ & 0.008 & 0.060 & $0.027(0.019)$ & 0.041 & 0.066 \\
\hline
\end{tabular}

Source: Researcher, 2021

\subsection{Hypothesis testing}

The relationship between bank efficiency and interest rate spread was determined through correlation and multiple regression analysis. Multicollinearity tests revealed a high collinearity between cost to income and return on assets and therefore cost to income ratio was dropped from the analysis. The direction and strength of correlation between bank efficiency variables and bank spread indicators were examined through the Pearson correlation matrix whose results are shown in table 2 above. The correlations are significant in all cases at the level of 0.01 . Additionally, all the correlations are with the expected signs. Much as there is a positive correlation between return on assets 
and interest rate spread the magnitude is small. On the other hand, the correlation between staff cost ratio and interest rate spread is positive and of a high magnitude. The correlation between gross margin and both independent variables is positive and significant with high correlation coefficients pointing to the high magnitude of the correlation.

The nature of relationship between efficiency and bank spread was further examined by regressing staff costs ratio and return on assets ratio on the spread indicators using the PCSE estimator. Cost to income ratio was omitted from this analysis after it was found to be highly collinear with return on assets. Assumptions of normality, linearity, and autocorrelation were done and an appropriate estimator for the analysis adopted. The model summary shows that independent variables were found to account for $53.39 \%$ of the variations in interest rate spread and the overall model has predictive power to explain the relationship between staff costs and return on assets with interest rate spread $(p=0.0000)$. The changes in bank spread attributable to individual variables as well as the significance of each are shown on the coefficients table 5 below. The relationship between staff costs and interest rate spread is significant and positive $(\mathrm{z}=11.53, p=0.000)$ at $p=0.05$. A unit change in staff costs results to a 1.99 units' increase in interest rate spread. The relationship for return on assets with interest rate spread is also significant and positive as expected $(\mathrm{z}=9.26, p=0.000)$ at $p=0.05$ with a unit change in return on assets resulting to a 0.796 units' positive change in interest rate spread.

The same independent variables were regressed with another measure of bank spread referred to in the study as gross margin and the results are presented in table 5 below. The overall model revealed that staff costs and return on assets accounted for $81.08 \%$ of the changes in gross margin and the model has predictive power at a $p$ value of $(\mathrm{p}=0.0000)$. The ratio of staff costs to assets had a positive and significant impact on gross margin $(\mathrm{z}=$ $24.45, p=0.000)$ at $p=0.05$. One unit of staff costs results is a 1.94 units' positive change in gross margin. Similarly, return on assets has a significant positive influence on gross margin $(\mathrm{z}=13.94, p=0.000)$ at $p=0.05$ with one unit of return on assets creating a positive change of 0.927 units of gross margin.

Table 5 Linear regression, correlated panels corrected standard errors (PCSEs)

\begin{tabular}{lcccccc}
\hline & \multicolumn{3}{c}{ IRS } & \multicolumn{3}{c}{ GRNIM } \\
& Coef. & $\mathrm{Z}$ & $\mathrm{P}>|\mathrm{z}|$ & Coef. & $\mathrm{Z}$ & $\mathrm{P}>|\mathrm{z}|$ \\
\hline SCR & 1.990426 & 11.53 & 0.000 & 1.942586 & 24.45 & 0.000 \\
ROA & .7958223 & 9.26 & 0.000 & .9269947 & 13.94 & 0.000 \\
\hline & R-squared $=0.5339 ;$ & Prob $>$ chi $2=0.0000$ & R-squared $=0.8108 ;$ & Prob $>$ chi2 $=0.0000$ \\
\hline
\end{tabular}

\section{Source: Researcher, 2021}

From the above correlation and regression analysis the following conclusions are made regarding the hypotheses under this objective:

$H 3 b$ : There is evidence of a significant positive relationship between staff costs and bank spread.

$H 3 c$ : There is a significant and positive relationship between return on assets and bank spread.

\subsection{Discussion of findings}

This study found both efficiency measures of staff costs ratio and return on assets ratio to have significant positive impact on bank spread thus upholding both $H 3 b$ and $H 3 c$. The findings point to a generally inefficient banking sector with an overall cost to income ratio of $66 \%$ and interest rate spread of $10.42 \%$ for the period under review. Cost to income ratio increased over the years irrespective of bank ownership, a reflection of the general business environment for the industry. Interesting to note is that staff costs remained stable with low indices throughout the same period suggestive of the fact that the rising costs are more as a result of a deteriorating asset quality. The non-performing loan book recorded an annual increase of over 10\% since 2011 up to 2018 (appendix table A 6). This increase is attributed to high interest rates especially in 2012, challenges in the business environment with two political elections during the period as well as enhanced loan classification and provisioning in line with Central Bank's prudential guidelines.

In his study of interest rate determinants in the Solomon Islands, Rebei (2014) found a significant positive relationship between interest rate spread and staff costs. Udom et al. (2016) found staff costs to be a positive and highly significant determining factor of interest rate spread in Nigeria. A finding that is similar with the current study and suggestive of banks passing on high staff costs to customers by way of increasing interest on loans or reducing interest on deposits or both. This position suggests the existence of agency problems within the industry. Comparatively, staff costs were found to have the highest impact with one unit change of staff cost resulting to a 1.9 units' change in bank spread. The positive relationship may be as a result of low employee productivity resulting in less than maximized revenues given the size of assets. There could be many reasons for low productivity ranging from skill gaps to insufficient deployment in areas that are critical for revenue maximization.

At $3 \%$ of assets, staff costs can be said to be high given the size of assets. There is need to have proper selfregulating mechanisms within the industry to check agency problems. The industry has widely adopted performance-based remuneration strategies which are a good mechanism for staff productivity and cost management. The downside of this tool however lies in the fact that the core measures are likely to be based on 
profitability and growth of the balance sheet. To achieve high performance on these measures, employees may take on lending risks that materialize into loan loss provisioning in subsequent years. To achieve the desired profitability in the wake of these provisions, banks will respond by increasing bank spread. In his study based on Ghanaian banks, Mensah and Abor (2012) also found a significant positive relationship between staff costs and interest rate spread. His conclusion was that indeed staff salaries and remuneration costs are taken into account in arriving at interest rates. Over the period under review, while staff cost ratio has remained flat, staff numbers increased up to 2013 and reduced in 2014 through to 2017 before increasing again in 2018. Over the same period between 2015 and 2018, staff cost ratio remained flat, even increased marginally by $0.5 \%$ for government-owned banks. Although the ratio was flat, actual staff costs increased in 2018 (CBK, 2018) suggesting that the flat staff costs ratio is more as a result of asset growth in the industry than reduced costs.

Bank spreads, staff costs ratio and return on assets maintained a flat trajectory throughout the period albeit on a reducing trend. This despite the exponential growth in the sector's balance sheet. This might be a reflection of the effects of the sustained deployment of technological channels in the sector to support the increased service requirements by an expanded customer base. In the Kenyan market, use of mobile banking technology has been embraced by banks to not only serve deposit mobilization and funds transfers but to also facilitate lending to customers. Indeed, in 2018, according to the Central Bank of Kenya Bank Supervision report (CBK, 2018), there were sixteen million mobile phone deposit account users together holding a total of ksh105 billion deposits. This accounted for $30.43 \%$ of industry deposit accounts and 3.1\% deposits in the industry. Out of these, seven million of them were active borrowers with a total exposure of ksh60 billion accounting for $97.49 \%$ of loan accounts and $2.41 \%$ of total loans value in the industry. The gains made possible through technology need to be supported by sufficient deployment of knowledgeable staff to offer relationship management and administration of the loan book.

The downward trend on return on assets could be explained by the effects of the interest rate capping or simply the inability to cope with the intense competition in this sector brought about by the entry of non-bank players to offer financial services with the aid of mobile enabled platforms. Return on assets ratio measures a bank's ability to generate revenue from assets owned and is an indicator of management's efficiency. As already seen, this measure was found to have a positive and significant relationship with interest rate spread. Banks may increase interest rates in a bid to increase revenues and attain higher profitability or to meet rising operating costs without affecting returns. Either way, this has the effect of widening the spread.

That banks indeed raise their interest margins to cover for costs was confirmed in the study on interest rate spread determinants done by Perez (2011). In this study where non-performing loans were found to have a significant positive influence on interest rate spread, its resultant cost was passed to customers in order to retain the desired profitability level. Over the period of the review, non-performing loans increased while profit after tax consistently accounted for $20 \%$ of the spread. This means that the costs incurred as a result of the loan loss provisions were passed onto the customers by way of increased interest on loans or reduced interest on deposits or both. The study recommended the adoption of risk based pricing and better loan appraisal methods to reduce interest rate spread and attain efficiency. Both Ghasemi and Rostami (2015) and Siddiqui (2012) found similar results in their studies confirming that banks indeed increase interest rate spread in order to maintain targeted profitability. Raharjo et al. (2014) found that banks in Indonesia actually raised interest rates in order to cover increased operating costs resulting to a positive relationship between return on assets and interest rate spread.

Peshev's (2015) conclusion in the case of commercial banks in Bulgaria was that the positive relationship was as a result of banks raising their lending rates and lowering deposit rates to raise profitability. In their study on interest rate spread and profitability in Ghanaian banks, Antwi et al. (2017) found return on assets to have a significant positive effect on interest rate spread pointing to a profit maximizing behaviour among the banks. Banks with higher profits relative to average assets tended to have higher lending rates and lower deposit rates. According to Afzal and Mirza (2012) the positive relationship he found in his study was as a result of efficient deployment of resources by banks. Similarly, the significant relationship between interest rate spread and return on assets in commercial banks in Oman was attributed to optimum use of assets (Al Shubiri \& Jamil, 2017). There is a great opportunity for Kenyan banks to optimize the use of their assets for higher profitability without resorting to increase of interest rate spread. One way would be by investing in proper training of staff in credit screening and in ensuring sufficient deployment of staff for proper customer relationship management and portfolio administration.

(Chortareas et al., 2012) found a significant negative relationship between X-efficiency and interest rate spread for Latin American countries indicating that greater efficiency within the banks' operations results in reduced interest rate spread. The study recommended policies that would encourage greater competition in the industry as well as incentivise banks to further enhance their operational efficiencies. Stronger economic growth would also support more efficiency gains in banks by reducing risk. 


\section{Conclusions and recommendations}

At a cost to income ratio mean of $66 \%$, Kenya's banking sector is cost inefficient. As a percentage of assets, staff costs are high at an average of $3 \%$ with the staff cost component taking up above $25.25 \%$ of total incomes generated by the sector $(\mathrm{CBK}, 2018)$. This may be attributed to the low rate of generation of income given the level of industry assets as is evidenced by the low return on assets ratio average mean of $3 \%$. Staff costs and return on assets maintained a flat trend throughout the period despite the exponential growth in the balance sheet pointing to the fact that, though technological innovation may have significantly contributed to business growth, the cost implication of this growth has cut down its positive contribution to net income. This study found both staff cost and return on assets to have a positive relationship with bank spread, a confirmation that indeed banks in Kenya do increase interest rate spread to cover for costs incurred in the process of their financial intermediation activities. This study is significant coming at a time when two major decisions touching on interest spread have been made in quick succession, with one being a decision to reverse the other. Indeed, a number of successive policy interventions have been made since the 1990's to try and address the issue of high interest rate spread without much success, at least judging by the common perception. Efficiency is an important factor for banks in Kenya in the wake of technological innovation and it is important to know how it relates to bank spread in order to make recommendations on where policy makers should focus on as they review regulations in line with the highly automated operating space.

Over the years, Kenya has introduced a raft of policy interventions to secure the efficiency of the financial sector in general and the banking sector in particular. Notable among them are the review of capital and cash ratio requirements earlier on to ease entry into the sector and encourage more lending respectively. Interest rate liberalization in the early $90 \mathrm{~s}$ was introduced to create an environment for competitive pricing. More recently, use of credit reference bureaus and the requirement for total cost of credit disclosure augmented by annual percentage rate disclosure were instituted to try and reduce opacity for customers in making cost effective borrowing decisions.

The competitive environment and onset of technological innovation have especially yielded positive results in the area of product diversification, deposit mobilization and general balance sheet growth. To a great extent this has resulted to some level of intermediation efficiency as seen in the reducing trend of interest rate spread in the period under review. These gains however appear to be undermined by growing bank operational inefficiency as seen in the rising cost to income ratio over the same period. As at the close of 2017, the sector cost to income ratio mean stood at $78 \%$ with operating costs taking up $63.6 \%$ of the total cost component. This situation is a hindrance to further intermediation efficiency gains as banks must cover for the high costs by maintaining wide interest rate spread. Banks must critically look internally at ways to cut on these costs. Going by the Central Bank of Kenya Bank Supervision Report of 2017, the significant contributors to this position of high costs are: Other operating expenses at $26.2 \%$, salaries and wages at $25.57 \%$ and bad debt provisions at $11.85 \%$ of total costs (CBK, 2017). Ways must be found to contain these runaway costs. Indeed, the regulator has enhanced risk classification and provision to ensure proper and timely recognition of risk but steps need to now be taken to curb the actual incidence of default. As at 2017, the sector non-performing debt stood at $9.69 \%$ of total debt while bad debts granted through technological platforms by banks stood at an even higher proportion of $12 \%$ of debts granted online. According to the same report, research has shown that access to credit without supervision increases the risk of default. Regulation to guide access in terms of individual limits and eligibility for mobile phone based lending specifically need to be formulated considering that it is not easy to apply the principles of prudent lending as contained in the prudential guidelines to this form of lending. Losses through fraud was also noted as another cause of high operating costs and which must be contained through ensuring system security and stability as well as proper internal control systems. Banks should also take the initiative to educate their customers continuously on how to guard against technology related fraud.

While mergers and acquisitions are encouraged to further strengthen the weaker banks and enable them compete effectively with the large banks the costs of loss of competition have been found to be too high where large banks merge or acquire smaller ones. If a market is dominated by a few banks, they can develop oligopolistic tendencies which reduces competition and increases inefficiency. On the other hand, mergers and acquisitions may achieve economies of scale and result in improved efficiency hence lower finance costs. Kenya appears to acknowledge this as one of its Vision 2030 policy actions is to facilitate transformation of the many small banks into fewer larger and stronger ones. Its aim is to ensure stability in the financial sector in the hope that the gains of a stable banking sector will be passed through to customers by way of more cost effective access to finance and other banking services. However, extant literature has shown that concentration does not necessarily translate into a competitive environment. In fact, a rise in concentration actually led to reduced competition as seen in the study of Competition, Efficiency and Interest Rate Margins in Latin American Banks (Chortareas et al., 2012). The trade-off between competition and bank stability must therefore be observed carefully by the regulators and policy makers.

The staff cost variable was found to be highly correlated to interest rate spread. Staff numbers reduced by $22 \%$ between 2014 and 2018 a reflection of the efficiencies afforded by the sustained implementation of technology 
enabled transaction channels. Over the period of the research, staff to customer ratio has grown from 325 customers per employee to 1733 customers per employee in 2018. This notwithstanding staff costs have continued to increase owing to salary increments an indication of the level of experience and performance of the employees which should be leveraged to drive more revenues. This study makes the following recommendations to achieve this:

First is that considering that banks have moved a great percentage of the everyday transactions to other technology supported channels, deliberate effort must be made to increase interaction time between staff and customers both physically and through other technology enabled plat forms. Such interactions should be meaningful and directed towards effective customer advice that will ensure the best interests of the customer's business and increased incomes for the bank. This implies that the employees must be well versed with bank operations as well as skilled to offer business advice. Lack of multi sector expertise has been known by past studies to impact performance of loans resulting in poor loan repayments. Diversification may have helped the mobilization strategy but lack of expertize in all sectors by staff may be contributing to high non-performance. Good business advice and enhanced relationship building will ensure increased wallet share for the bank as well as better servicing of advanced loans hence improved incomes. Much as technology has enabled coverage of more customers by a single employee, there is still need to come up with models for optimum portfolio loading. Determining the maximum number of customers one employee can effectively serve is critical to ensure proper relationship management and timely interventions where customers have changing business needs. The banks can also leverage on technology to offer customers applications that help them keep simple financial records of their businesses as they transact with the bank. Such information will later be useful for the bank when assessing repayment ability for loans applied.

Training in credit appraisal and administration is imperative to maintain a well performing loan book and banks need to invest more on this. It is recommended that regulators identify professional banking certifications that address such skills and ensure staff charged with lending and portfolio administration possess them.

Finally, recognising that most banking institutions have embraced performance based reward policies, it is important to take stock of the components that are measured per employee to see that the same is not encouraging poor appraisals and mis-selling of products by staff just to meet set targets. To further support this, banks, in collaboration with the relevant associations and the regulator, need to consider certification for bankers so that employees adhere to a common code of professional standards when dealing with customers irrespective of the bank they work for. A good area for further research is on how performance-based remuneration schemes affect bank spread.

Return on assets at an overall ratio mean of $2.8 \%$ and a downward trend with some banks recording losses towards the end of the study period is an indication that banks in Kenya are not efficient in the use of their assets to generate profits. This study found that return on assets had a positive and significant relationship with interest rate spread. Faced with the overwhelming costs already discussed above, banks tend to increase interest rate spread in order to continue meeting the set profitability goals. Banks must find ways of ensuring all assets are effectively managed and deployed to maximize revenue generation. In the wake of technological innovation, banks must review their banking models and as the society moves towards a cashless economy release some of their idle assets that were held mainly to facilitate cash transactions so that these can be deployed to gainful investment outlets. These include cash holdings and buildings. This will also go a long way in reducing their associated costs hence further contributing to profitability. It is noted that as at 2017 , loans and advances made up only $50.3 \%$ of total assets and even then, over $9 \%$ of it was non-performing. Concerted effort must be put to grow the good book and step up collection to ensure recoverability of the non- performing debts. $36.7 \%$ of the sector's assets were held in government securities and fellow banking institutions. Government has a role to play in encouraging banks to lend more to the private sector to facilitate better revenue generation from these assets. The business operating environment could be helped more with the relevant government agencies facilitating easy access to required licences and certification for production and sale of goods both locally and internationally. Government should also implement taxation models that encourage business people to invest more and generate more cash flows. This would go a long way in reducing the incidences of default in bank loans thus reducing risk premiums for loans.

\section{References}

Afzal, A., \& Mirza, N. (2012). Interest Rate Spreads in an emerging economy: The Case of Pakistan's Commercial Banking Sector. Economic Research, 25(4), 987-1004. https://doi.org/10.1080/1331677X.2012.11517543

Ahokpossi, C. (2013). Determinants of Bank Interest Margins in Sub-Saharan Africa (WP/13/34).

Al Shubiri, F. N., \& Jamil, S. A. (2017). Assessing the determinants of interest rate spread of commercial banks in Oman: An empirical investigation. European Research Studies Journal, 20(2), 90-108.

Antwi, G. O.-, Banerjee, R., \& Antwi, J. (2017). Interest Rate Spread on Bank Profitability: The Case of Ghanaian Banks. Journal of Accounting, Business and Finance Research, 1(1), 34-45. https://doi.org/10.20448/2002.11.34.45

Bader, M., Mohamad, S., Ariff, M., \& Hassan, T. (2008). Cost, revenue and profit efficiency in islamic vs. 
Conventional banks: Empirical evidence using data envelopment analysis (DEA). Islamic Economic Studies, 15(2).

Ben Khediri, K., \& Ben-Khedhiri, H. (2011). Determinants of bank net interest margin in tunisia: A panel data model. Applied Economics Letters, 18(13), 1267-1271. https://doi.org/10.1080/13504851.2010.534052

Bonga, W. G. (2016). An Empirical Analysis of the Determinants of Interest Rate Spreads : A Case of Commercial Banks in Zimbabwe (Issue September). Great Zimbabwe University.

CBK. (2015). Statistical Bulletin, December 2015. December.

CBK. (2017). Central Bank of Kenya.

CBK. (2018). Bank http://www.centralbank.go.ke/downloads/bsd/annualreports/bsd2010.pdf

Chortareas, Georgios E.; Garza-Garcia, Jesus G.; Girardone, C. (2009). Market Structure , Profits , and Spreads in the Mexican Banking Industry. (Paper Number : 09 / 09; Working Paper Series ( ISSN 2041-1596 )).

Chortareas, G. E., Garza-García, J. G., \& Girardone, C. (2012). Competition, efficiency and interest rate margins in Latin American banking. International Review of Financial Analysis, 24(55), 93-103. https://doi.org/10.1016/j.irfa.2012.08.006

Dhal, S. C., \& Ansari, J. (2013). Interest Rate Pass-through and Determinants of Commercial Banks 'Loan Pricing Decisions in India : Empirical Evidence from Dynamic Panel Data Model.

Dumicic, M., \& Ridzak, T. (2016). Determinants of banks' net interest margins in Central and Eastern Europe. ResearchGate, March 2013. https://doi.org/10.3326/fintp.37.1.1

Georgievska, Ljupka; Kabashi, Rilind; Trajkovska, Nora Manova; Mitreska, Ana; Vaskov, M. (2011). Determinants of lending interest rates and interest rate spreads (ISSN 1792-6564; Issue February). Bank of Greece Printing Works.

Gesang Raharjo, P., Budiman Hakim, D., Hayman Manurung, A., \& Maulana, T. N. (2014). The Determinant of Commercial Banks' Interest Margin in Indonesia: An Analysis of Fixed Effect Panel Regression. International Journal of Economics and Financial Issues, 4(2), 295-308. www.econjournals.com

Ghasemi, A., \& Rostami, M. (2015). Determinants of interest rate spread in banking industry. International Journal of Applied Research, 1(9).

Giordano, Luca; Lopez. (2015). Competition Versus Efficiency : What Drives Banks ' Spreads in Italian Banking System? Competition versus Efficiency: What Drives B anks '. ResearchGate, June. https://doi.org/10.2139/ssrn.2640899

Gounder, N., \& Sharma, P. (2012). Determinants of bank net interest margins in Fiji, a small island developing state. Applied Financial Economics, 22(19), 1647-1654. https://doi.org/10.1080/09603107.2012.674202

Heale, R., \& Twycross, A. (2015). Validity and reliability in quantitative studies. Evidence-Based Nursing, 18(3), 66-67. https://doi.org/10.1136/eb-2015-102129

Ho, S.Y. Thomas; Saunders, A. (1981). The Determinants of Bank Interest Margins: Theory and Empirical Evidence. Journal of Financial and Quantitative Analysis, XVI(4), 581-601.

Kamarudin, F., Sufian, F., Nassir, A. M., Anwar, N. A. M., \& Hussain, H. I. (2019). Bank Efficiency in Malaysia a DEA Approach. Journal of Central Banking Theory and Practice, 8(1), $133-162$. https://doi.org/10.2478/jcbtp-2019-0007

Kiptui, M. C. (2014). Determinants of Interest Rate Spread : Some Empirical Evidence from Kenya's Banking Sector. International Business Research, 7(11), 94-107. https://doi.org/10.5539/ibr.v7n11p94

Koffie, A. N., Edder, M., \& Pineda. (2014). Determinants of Banks' Net Interest Margins in Honduras. In IMF Working Paper (Vol. 14, Issue 163). https://doi.org/10.5089/9781498317931.001

Männasoo, K. (2012). Determinants of Bank Interest Spread in Estonia. In Working Paper (1/2012; Working Paper Series, ISSN 1406-7161).

Maudos, J., \& Fernández De Guevara, J. (2004). Factors explaining the interest margin in the banking sector of the European Union. Journal of Banking and Finance, 28, 2259-2281.

Mensah, S., \& Abor, J. (2012). Agency Conflict and Bank Interest Spreads in Ghana (Issue December).

Mohajan, H. K. (2017). Two Criteria for Good Measurements in Research: Validity and Reliability. Annals of Spiru Haret University. Economic Series, 17(4), 59-82. https://doi.org/10.26458/1746

Moundigbaye, M., Rea, W. S., \& Reed, W. R. (2018). Which panel data estimator should i use?: A corrigendum and extension. Economics, 12(February). https://doi.org/10.5018/economics-ejournal.ja.2018-4

Mwega, F. M. (2014). Financial regulation in Kenya : Balancing inclusive growth with financial stability (WP 407; Issue November).

Perez, P. (2011). Determinants of Interest Rate Spread in Belize.

Peshev, P. (2015). Determinants of Interest Rate Spreads in Bulgaria Determinants of Interest Rate Spreads in Bulgaria (DP/99/2015).

Raharjo, P. G., Hakim, D. B., Manurung, A. H., \& Maulana, T. N. A. (2014). The Determinant of Commercial Banks 'Interest Margin in Indonesia : An Analysis of Fixed Effect Panel Regression 1. International Journal 
of Economics and Financial Issues, 4(2), 295-308.

Rebei, N. (2014). Determinants of Interest Rate Spreads in Solomon Islands.

Romero, Jose Pablo Barquero; Rodriguez, C. S. (2011). Determinants of interest rate spread in Costa (No. 032011; Issue 03). Central Bank of Costa Rica, Economic Research Department.

Rusuhuzwa, T. K., \& Karangwa, Mathias; Nyalihama, C. (2016). Determinants of interest rate spread in Rwanda : Empirical evidence. Issues in Business Management and Economics, 4(May), 33-40.

Siddiqui, M. A. (2012). Towards determination of interest spread of commercial banks: Empirical evidences from Pakistan. African Journal of Business Management, 6(5), 1851-1862. https://doi.org/10.5897/AJBM10.929

Udom, I. S., Agboegbulem, N. T. I., Atoi, N. V, Adeleke, A. O., Abraham, O., Onumonu, O. G., \& Abubakar, M. (2016). Modelling banks ' interest margins in Nigeria. CBN Journal of Applied Statistics, 7(1), 1-26.

Ugur, A., \& Erkus, H. (2010). Determinants of the Net Interest Margins of Banks in Turkey. Journal of Economic and Social Research, 12(2), 101-118.

Valverde, C. S; Fernandez, F. R. (2007). The determinants of bank margins in European banking. Journal of Banking and Finance, 31(7), 2043-2063. https://doi.org/10.1016/j.jbankfin.2006.06.017

\section{Appendix}

Appendix tables

Table A 1 World interest rate spread

\begin{tabular}{lllllllllll}
\hline & 2009 & 2010 & 2011 & 2012 & 2013 & 2014 & 2015 & 2016 & 2017 & 2018 \\
\hline IRS & 5.93 & 6.028 & 6.024 & 5.836 & 5.853 & 5.715 & 5.332 & 5.716 & 5.453 & 5.504 \\
\hline
\end{tabular}

Source: World Bank Group (US) https://data.worldbank.org/indicator/FR.INR.LNDP accessed on $\underline{13 / 4 / 2021}$

Table A 2 Sector staff costs to other operating costs ratio

\begin{tabular}{llll}
\hline Year & Staff Costs & Other Operating Costs & Ratio \\
\hline $\mathbf{2 0 1 8}$ & 91090 & 222458 & $41 \%$ \\
$\mathbf{2 0 1 7}$ & 90298 & 224691 & $40 \%$ \\
$\mathbf{2 0 1 6}$ & 84761 & 219464 & $39 \%$ \\
$\mathbf{2 0 1 5}$ & 79873 & 198282 & $40 \%$ \\
$\mathbf{2 0 1 4}$ & 75371 & 202181 & $37 \%$ \\
$\mathbf{2 0 1 3}$ & 68820 & 167596 & $41 \%$ \\
$\mathbf{2 0 1 2}$ & 59546 & 188860 & $32 \%$ \\
$\mathbf{2 0 1 1}$ & 52435 & 114447 & $46 \%$ \\
$\mathbf{2 0 1 0}$ & 47042 & 103708 & $45 \%$ \\
$\mathbf{2 0 0 9}$ & 38837 & 88442 & $44 \%$ \\
$\boldsymbol{T O T} \boldsymbol{A L}$ & 688073 & 1730129 & $40 \%$ \\
$\boldsymbol{A V E R} \boldsymbol{A G E}$ & 68807 & 173013 & $40 \%$ \\
\hline
\end{tabular}

Source: Bank Supervision reports 2010-2018 and researcher's own calculations

Table A 3 Kenya's percentage annual inflation rate

\begin{tabular}{lrrrrrrrrrr}
\hline \hline & 2009 & 2010 & 2011 & 2012 & 2013 & 2014 & 2015 & 2016 & 2017 & 2018 \\
\hline \%Av. annual inflation & 10.5 & 4.1 & 14 & 9.4 & 5.7 & 6.9 & 6.6 & 6.3 & 8 & 4.7 \\
\% Av. annual T. Bill rate & 7.38 & 3.60 & 8.73 & 12.76 & 8.93 & 8.93 & 10.93 & 8.51 & 8.37 & 7.76 \\
\hline
\end{tabular}

Source: Economic survey (KNBS) and CBK, 2019, 2018, 2017,2016,2014,2012 \& 2011

$\underline{\text { Table A } 4 \text { Annual trends for interest rate spread and gross margins }}$

\begin{tabular}{lcccccccccc}
\hline & 2009 & 2010 & 2011 & 2012 & 2013 & 2014 & 2015 & 2016 & 2017 & 2018 \\
\hline IRS & .1070 & .1110 & .1150 & .1200 & .1100 & .1030 & .0980 & .0980 & .0800 & .0810 \\
GRNIM & .1180 & .1170 & .1070 & .1080 & .1020 & .1010 & .1010 & .1030 & .0890 & .0880 \\
\hline
\end{tabular}

Source: Researcher, 2021

Table A 5 Non -performing loans ratio as at 2018

\begin{tabular}{lccc}
\hline & Loans & Bad debts & NPL ratio \\
\hline GOVT & 56208436 & 34000000 & $60 \%$ \\
PRIVATE & 1674194233 & 196092774 & $11.7 \%$ \\
\hline
\end{tabular}

Source: Researcher, 2021 
Table A 6 Banking sector annual growth of NPL and NPL ratio

\begin{tabular}{rrrrr}
\hline YEAR & Total loans & NPL & NPL\% growth & NPL ratio \\
\hline 2009 & 757760 & 111700 & & $15 \%$ \\
2010 & 914910 & 98443 & $-12 \%$ & $11 \%$ \\
2011 & 1190985 & 108180 & $10 \%$ & $9 \%$ \\
2012 & 1330365 & 137532 & $27 \%$ & $10 \%$ \\
2013 & 1578768 & 193105 & $40 \%$ & $12 \%$ \\
2014 & 1940781 & 233017 & $21 \%$ & $12 \%$ \\
2015 & 2165329 & 324896 & $39 \%$ & $15 \%$ \\
2016 & 2293190 & 468513 & $44 \%$ & $20 \%$ \\
2017 & 2413851 & 563005 & $20 \%$ & $23 \%$ \\
2018 & 2488117 & 622079 & $10 \%$ & $25 \%$ \\
\hline
\end{tabular}

Source: CBK Bank Supervision reports and researcher's calculations

\section{Appendix figures}

Figure A 1. Validity tests

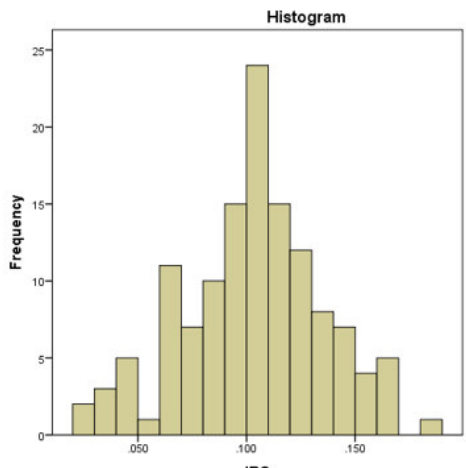

IRS

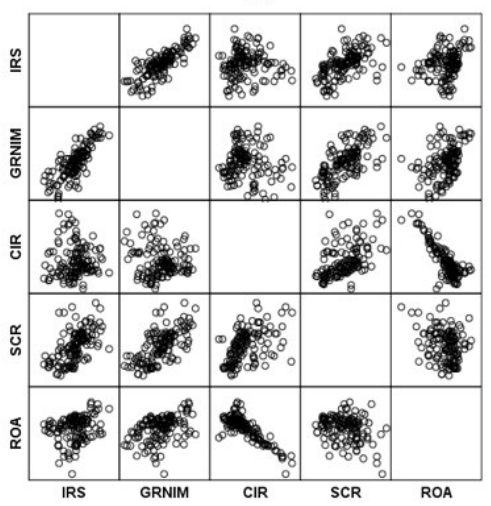

Source: Researcher, 2021
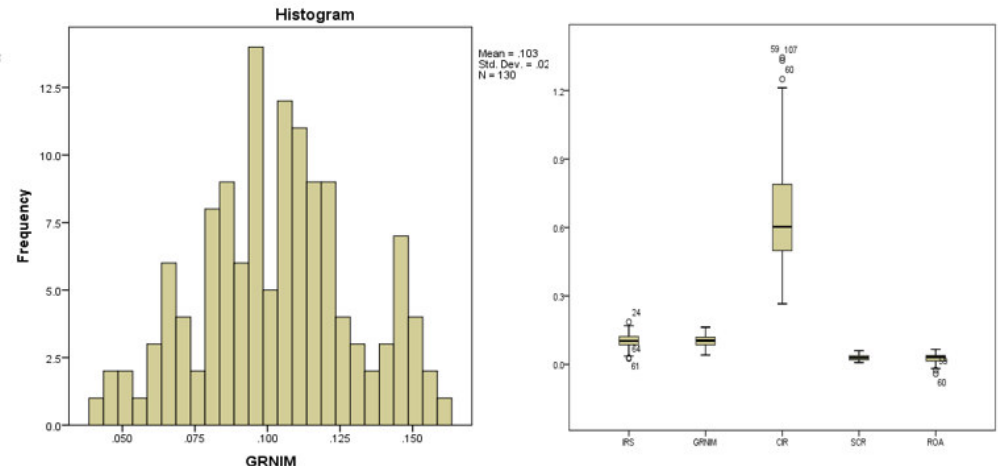

Scatterplot
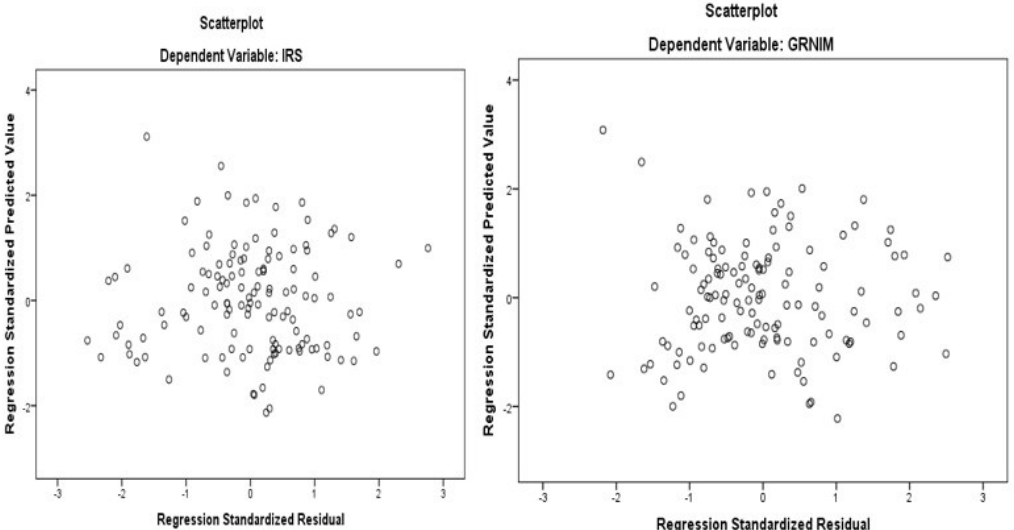